\title{
Velázquez y los Secretarios de Estado. Vicisitudes flamencas de unos retratos del Conde-Duque *
}

1. ATRIBUCIONES, CRITERIOS ESTILÍSTICOS, Y PRAGMÁTICA DE LA OBRA DE ARTE

Las reatribuciones de obras de arte que últimamente se suceden e invalidan con no vista rapidez son, para la persona poco entendida en cuestiones artísticas, motivo de no menor perplejidad. Así, por ejemplo, al saberse que el Metropolitan Museum dictaminó recientemente que trescientos de sus cuadros de autores europeos no son en realidad de la mano que se suponía y que, en consecuencia, se les cambiaría el rótulo ${ }^{1}$, el profano sentirá cierto escepticismo y curiosidad por los criterios estilísticos y medios técnicos $\longrightarrow$ el uso que de ellos se hace- que decidieron de

* [Don Julio Caro Baroja está muy presente en la redacción y en la pequeña historia de este trabajo. El rechazo a determinadas concepciones sobre Velázquez, según se reflejaban en la obra de un autor teatral que no eran muy de su agrado (ni el autor ni la obra), subyace en un breve artículo suyo dedicado a la personalidad del pintor en 1963. Con mayor vehemencia solía años después aludir en conversaciones privadas a ese Velázquez presuntamente "contestatario". Por entonces reuní los datos de archivo sobre los retratos del Conde-Duque, y fue él quien me señaló la conveniencia de publicarlos. El artículo, terminado en 1974, debió mucho también al estímulo de D. ${ }^{a}$ Herminia Allanegui y D. José Muguruza, amigos y contertulios habituales de Don Julio. Pero no llegó a publicarse. A algunos especialistas en pintura española del s. XVII no les resultó grato el tono poco reverencial que se adoptaba ante la crítica de arte. No creo que fuera para tanto. Torpezas juveniles e ingenuidades aparte, en ese tono también está presente Don Julio, que por esas fechas había escrito algo parecido a que "quienes no somos profesores de literatura podríamos a veces poner más de un suspenso a quienes lo son". Por la misma razón, no veo por qué quienes no somos especialistas en arte no podríamos a veces poner modestas objeciones a lo que se nos exhibe como ciencia rigurosa e incontestable.

El caso es que al releer ahora un trabajo de hace 22 años lo único que de él no me desagrada es, precisamente, su indisimulada impronta carobarojiana. Como, por otro lado, no veo que contenga dislates de más de la marca y creo que los datos documentales conservan su valor, me atrevo a ofrecerlo, con correcciones mínimas y alguna ampliación, en homenaje a las "sombras" en torno a Velázquez trazadas por Don Julio, y en recuerdo a su ausencia, cada vez más dolorosamente viva].

1 Carter B. HoRSLEY, "Who Really Painted It? The Met's Downgrading of 300 Works of Art", Art News, March 1973, pp. 46-49. 
golpe la reatribución de nada menos que el quince por ciento de los fondos de pintura europea de este museo. $\mathrm{O}$ ante los criterios que en su día, nada lejano en muchos casos, habían asentado con parecido dogmatismo las autorías que ahora se modifican.

El escepticismo no puede menos que acrecentarse al conocer la crítica bien fundada de, al menos, una de tales reatribuciones. Don José LópezRey ha probado que en un caso el cambio de atribución ha sido injustificado ${ }^{2}$. El retrato de Felipe IV considerado hasta hoy obra de Velázquez no lo es a juicio de Mr. Everett Fahy, principal responsable de los cambios aludidos; sobre qué débiles bases se funda esta apreciación es lo que ha expuesto convincentemente López-Rey. Los análisis proporcionados por los rayos $\mathrm{X}$, la existencia de pentimenti que éstos revelan, la labor de restauradores antiguos o pertenecientes al staff del Museo, etc., fueron interpretados en el Metropolitan con rara ligereza, o bien pura y simplemente ignorados. Lo mismo sucede con la evidencia documental sacada a luz por Mélida a principios de siglo, y de la que ahora parece haberse preferido hacer caso omiso. $\mathrm{Y}$ sin embargo, un recibo escrito y firmado por el pintor es algo que en principio debiera haberse tomado en consideración. De hecho, fue esa evidencia documental la que vino a motivar, ya en 1905, el cambio de opinión de Beruete para llegar, en 1911, a la reafirmación concluyente de que el retrato es obra del pintor sevillano. Esta apreciación fue compartida en años sucesivos por varios otros estudiosos y es ahora confirmada de nuevo por López-Rey, que añade otras pruebas estrictamente técnicas ${ }^{3}$. De todo ello puede concluirse que, en palabras del autor citado, "Technological devices, helpful as they are, can not be more than tools for the connoisseur. He still has to evaluate the date at hand - stylistic, documentary, technological, etc." ${ }^{4}$.

Esto nos da pie para presentar aquí algunos nuevos datos documentales, único aspecto en que la aportación del no especialista puede ser de alguna utilidad; datos que atañen a otros retratos de Velázquez, esta vez del Conde-Duque, en los que no dejan de presentarse problemas de autoría

2 J. LÓPEZ-REY, "The Reattributed Velázquez: Faulty Connoisseurship", en la misma revista, pp. 50-52. Debí el conocimiento de este trabajo y el anterior a la amistad de D. José Muguruza.

3 Cf. J. R. MÉlIDA, "Un recibo de Velázquez", $R A B M$, XIV (1906), pp. 173-198. Al conocer el documento descubierto por Mélida, Beruete rectificó su opinión anterior de que el retrato no representaba a Felipe IV sino a su hermano, el Cardenal Infante, y que se trataba de una copia. Como lo recuerda López-Rey, esa primera opinión del "experto" fue causa de que el Museo del Prado rechazase la oferta de adquirir el cuadro, razón por la que actualmente se encuentra en el Metropolitan.

4 J. LÓPEZ-REY, art. cit., p. 50. 
y que ahora acaso puedan, en cierta medida, esclarecerse. La nueva información se halla desperdigada en la correspondencia diplomática de Flandes en época del gobierno del Cardenal-Infante. Al margen del mayor o menor interés que esa información pueda ofrecer para la historia del arte, las cartas que la contienen se prestan a algunas reflexiones sobre lo que ha dado en llamarse pragmática de la obra de arte, entendida como estudio del origen, usos y efectos del objeto artístico ${ }^{5}$; en términos más familiares se diría que aportan algo a la historia cultural del periodo. Hacerse cargo de tales orígenes, usos y efectos supone entrar en ciertos antecedentes que tal vez parezcan superfluos desde la perspectiva de quien admira, con toda justicia, al gran pintor en la paz del Museo. No lo serán si no se pierde de vista la obvia integración del artista y su obra en el contexto histórico que le tocó vivir; y sobre todo su papel, en cuanto adscrito a la cámara de Felipe IV y dentro de los "aparatos del Estado" de la Monarquía hispánica. El periodo de los Austrias puso en primer plano algo que podríamos denominar el "aparato ornamental", o representativo del Estado, que es cosa muy distinta del "mecenazgo", categoría a la que suele referirse habitualmente la significación del interés por las artes mostrado por los monarcas españoles de los siglos XVI y XVII. Volveremos sobre ello, pero vamos antes a acercarnos a otro tipo de servidores del Estado.

\section{ENTRE BURÓCRATAS}

La burocracia de los gobiernos y virreinatos de la Monarquía hispánica en Europa reproduce en gran medida, durante el siglo XVII, los modelos que hallamos en la propia burocracia peninsular. Así, ciñéndonos al Flandes de los Habsburgo entre 1635 y 1641, hallaremos el mismo complicado sistema de consejos, algunos de ellos específicos del territorio, que han de ser consultados por el gobernador en cualquier decisión que afecte a sus competencias. El gobernador, por su parte, mantiene su propia secretaría de cámara, nombra directamente a quienes desempeñan determinados oficios que son de atribución real, y coloca a algunas personas de su confianza en los consejos colaterales. Veremos, así, moverse en torno a las grandes figuras del gobierno político y militar toda una constelación de funcionarios de distinto rango: secretarios y oficiales "de pluma", con-

5 Charles MORRIs, "Art, Signs and Value", cap. IV de Signification and Significance. Existe traducción castellana, que estuvo a mi cargo, de este libro: La significación y lo significativo (Madrid: Comunicación, 1974). 
tadores, pagadores, veedores, superintendentes de la justicia militar, auditores y un largo largo etcétera de otros funcionarios que ejercían sus oficios de acuerdo con nombramientos y "patentes" sacadas de los mismos formularios que las de sus colegas en la Península. Entre quienes más directamente tenían que ver con las secretarías de la corte de Bruselas y del ejército predominan, como es tópico insistente en la literatura coetánea, los de apellido vasco ${ }^{6}$ : Mateo López de Iñarra, Martín de Axpe, Diego de Hernani, Francisco de Galarreta, Diego de Ibarra, tienen que ver en un momento u otro con los papeles del Cardenal-Infante; Juan de Necolalde es el Veedor general del ejército, Alonso de Uribarri tiene a su cargo el aprovisionamiento de la armada, etc. Junto a ellos se señala la presencia de dos burgaleses llamados a desempeñar años más tarde funciones importantes en la corte de Madrid: Miguel de Salamanca y Pedro Fernández del Campo. La carrera de honores que siguen estos personajes suele ser lenta pero cuentan con la ventaja de hallarse menos expuestos a caídas e inseguridades que quienes ejercen funciones más brillantes y efímeras. Lo que empieza por una simple habilidad de pendolista puede llevar al cabo de algunos años a merecerles un hábito $\mathrm{y}$, siempre que medien protectores, a ir escalando puestos de cada vez mayor confianza; muchos acaban consiguiendo asiento en alguno de los reales consejos, embajadas, matrimonios ventajosos para sus hijos y, en ocasiones, un título nobiliario.

Por otra parte, el poder efectivo que podía tener en la época un secretario es muchas veces desproporcionado si se compara con la escasa memoria de sus personas que se conserva en la Historia al uso. Este poder, poco manifiesto, derivará unas veces del contacto directo con los mandarines de turno; otras se deberá a la auténtica competencia que adquieren por la simple permanencia prolongada en unas funciones idénticas o similares. En los años que median entre 1634 y 1647, por ejemplo, se suceden en Bruselas nada menos que siete gobiernos distintos; pero a lo largo de todos ellos el secretario Miguel de Salamanca no ha dejado de desempeñar puestos de responsabilidad 7 . Ello lo convierte en insustituible cada vez que se produce el cambio; conoce bien el país, las personas, la lengua; disfruta, además, de la confianza de Olivares y reali-

6 Cf. M. Herrero García, Ideas de los españoles del siglo XVII (Madrid: Gredos, 1966); A DE LEGARDA, Lo "vizcaíno" en la literatura castellana (S. Sebastián, 1953), cap. 7; J. CARO BAROJA, los vascos y la bistoria a través de Garibay (S. Sebastián: Txertoa, 1972), pp. 57 y ss.

7 Los gobiernos son los del Marqués de Aytona (interino), el del Cardenal-Infante, una Junta transitoria a la muerte de éste, el de D. Francisco de Melo, el gobierno conjunto del Marqués de Castel-Rodrigo y el general Piccolomini, el que ejerce CastelRodrigo en solitario, y el del Archiduque Leopoldo de Austria. 
za viajes periódicos a Madrid, donde recibe instrucciones o mueve por su cuenta los hilos del poder central.

Los principios de Salamanca son, sin embargo, bastante modestos. Alcalde de Burgos y procurador por su ciudad en las Cortes de $1632^{8}$, administrador luego de la renta de millones, da el primer salto a Flandes como veedor y contador de la artillería en 1634. Los superiores debieron de quedar satisfechos de su gestión y así lo vemos tres años después convertido en la persona de confianza que el Cardenal-Infante envía a la corte de su hermano. Su misión era ante todo negociar y facilitar la rapidez en las consignaciones de los asientos y provisiones militares. Es ahora cuando el Conde-Duque echa de ver en el secretario ciertas aptitudes diplomáticas, y con la protección del valido comienza el encumbramiento de Salamanca. Así no es de extrañar que se le encomienden algunas misiones de carácter extraordinario, y viaje a Portugal poco antes de la sublevación en misión secreta y poco clara de pacificador, o de delator ${ }^{9}$. En dos viajes de vuelta a Flandes se entrevista con Richelieu y trata de hacerlo con Mazzarini para tantear las posibilidades de ajustar la paz. En otra ocasión recibirá el encargo de apresar a Don Duarte de Braganza, asunto en que el privado fiaba poco menos que la recuperación de Portugal; para este cometido recibe instrucciones precisas de Felipe IV en las que se le autoriza para servirse de la colaboración del general Piccolomini, o de los judíos establecidos en Holanda, siempre que sirvan para asegurar el éxito ${ }^{10}$. Salamanca lleva a buen término el prendimiento pese a toda clase de protestas diplomáticas y recibe los parabienes. Más sorprendente es que algunos años más tarde el parecer del secretario pudiera prevalecer sobre el de personas mucho más importantes que él en un asunto de

8 Cf. M. Danvila y Collado, El poder civil en España, cit. en Bol. de la comisión prov. de monumentos de Burgos, IX, núm. 31 (1930), p. 39. Varios otros datos sobre la etapa de Miguel de Salamanca como procurador se hallan en AHN, Estado, lib. 961. No encuentro referencias al personaje en trabajos de historiadores burgaleses, pero sí sobre su familia; cf. I. García Rámila, "Memorables instituciones burgalesas: la "Cofradía o hermandad de los treze”", BRAH, CXXXIX (1956), pp. 41 y ss. Se transcriben ahí extractos de las pruebas de ingreso en la orden de Alcántara hechas por un Antonio de Salamanca en 1620; un testigo afirma que "sabe que estos linajes de Salamanca y Polanco son de los más nobles, principales y antiguos que hay en esta ciudad de mayor notoriedad". Además del linaje, hay que contar con la postura sumisa que Salamanca adoptó ante los intereses de la Corona en las citadas Cortes de 1632 para explicar los inmediatos ascensos del procurador.

9 Resulta irónico que una de las personas con quien Salamanca se entrevistó es el futuro Juan IV, sobre cuya fidelidad Olivares no abrigaba por entonces, 1637, ninguna sospecha.

10 Cf. AHN, Estado, lib. 963, ff. 16-17.p 
capital interés para la monarquía española. Pero eso es lo que ocurre cuando en 1646 se busca un gobernador para las "Provincias obedientes" de los Países Bajos que reemplace al Marqués de Castel Rodrigo. La sugerencia de Salamanca de que se eligiese al Archiduque Leopoldo de Habsburgo se impuso a la opinión de hombres de Estado tan notables como el Conde de Peñaranda, el Duque de Terranova, o el mismo Castel Rodrigo, quienes en cartas bastante pintorescas protestan y describen al candidato como un almacén de tachas, salvo en la beatería; y hay que admitir, a posteriori, que tenían razón. El propio Salamanca tampoco estaba al final muy conforme con su anterior sugerencia, pero el mecanismo burocrático no permitía volverse atrás, y él mismo será el encargado de viajar a Viena y organizar el traslado a Bruselas del Archiduque y su casa. Realizado el trabajo, el secretario obtiene licencia y puede retirarse tranquilamente a Madrid a disfrutar de su plaza de Consejero de Hacienda; otros serán los que tengan que habérselas con el príncipe taimado e incapaz, además de beato.

De la gestión de Salamanca en los estados de Flandes han quedado treinta libros, algunos muy gruesos, de correspondencia y documentos varios ${ }^{11}$. Pese a que el resto de su actividad nos es casi enteramente desconocido aún lo sorprenderemos en 1658 adquiriendo un señorío por compra -el de Canillejas-, forma habitual de rubricar el ascenso a una situación paranobiliaria de "señor de vasallos" ${ }^{12}$; o en 1660 dando su parecer en una consulta sobre asuntos económicos ante el Consejo de Hacienda, del que llegó a ser presidente ${ }^{13}$; y su actividad debía de tener la suficiente importancia como para merecer las invectivas de sus contemporáneos en forma de sátira ${ }^{14}$.

11 AHN, Estado, libros 954 a 983, incorporados a la sección en fecha reciente por D. ${ }^{a}$ Pilar León Tello. Se advierte, sin embargo, que faltan algunos tomos, entre ellos los que debían de contener la parte más sustancial de cartas del Conde Duque. Para seguir la carrera personal de Salamanca el libro que tiene un mayor interés es el núm. 961.

12 Cf. A. Domínguez Ortiz, "Ventas y exenciones de lugares durante el reinado de Felipe IV", $A H D E$ (1965), pp. 175 y 182-183.

13 Cf. "Voto de D. Miguel de Salamanca sobre los arbitrios propuestos para la recuperación de Portugal", 18 octubre de 1660, en A. Domínguez OrTIZ, Política $y$ Hacienda de Felipe IV (Madrid, 1960), apéndice XV, pp. 378-380.

14 Se conoce un escrito que satiriza a varios personajes en la forma de un cartel teatral: "Comedia famosa de tres yngenios, los mejores de España. Jornada primera: la que hiço el Conde de Castrillo a Vallecas. Jornada segunda: la que hace el Duque de Medina a Palacio cargado de noticias del Norte. Jornada tercera: la que hizo el Conde de Peñaranda desde Nápoles a Madrid a executar los disignios del Abad Arnor. Invenciones de Joseph González; tramoyas de Góngora; sainetes de Salamanca; bailes 
Pero en la época que ahora nos interesa, el caballero de Santiago, secretario de Estado y Guerra, Mayordomo mayor de Don Juan José de Austria, Alcalde perpetuo de Burgos, Consejero y Presidente de Hacienda, etc., no ha hecho apenas más que comenzar su ascenso.

\section{SALAMANCA EN MADRID; Y UN ENCARGO DE BRUSELAS ("UN PINTOR QUE DICEN SE LLAMA VELÁZQUEZ")}

A fines de 1636 el Infante comisiona a su secretario para que realice diversas gestiones en la corte de España. La estancia de don Miguel en Madrid se prolongó mucho más de lo previsible; en total, más de un año de juntas, entrevistas con miembros de distintos Consejos de la Monarquía, antesalas y dilaciones de todo tipo. Las cartas del secretario revelan impaciencia y hastío: ni se le despacha ni se le permite abandonar la corte; no puede, incluso, obtener licencia para ir a Burgos unos días a ocuparse de asuntos familiares. Pendiente en todo momento de su regreso a Bruselas, don Miguel entretiene sus ocios como puede y no deja de mantenerse bien informado de lo que sucede en Flandes a través, sobre todo, de una asidua correspondencia con Francisco de Galarreta, por entonces secretario de Estado interino del Infante. Galarreta aparece en sus cartas como un hombre maldiciente y dotado de cierta capacidad para ingeniosidades verbales ${ }^{15}$. Ello, sumado a la amistad entre dos personas del mismo oficio, ambos hechuras de Olivares, con preocupaciones comunes y parecidas simpatías o antipatías, presta a la correspondencia que se intercambiaron una animación y viveza que no es habitual en otras cartas de los mismos personajes. Salamanca informa de la lenta marcha de los asuntos que le habían traído a Madrid, a los que se añade ahora

de D. Luis de Oyanguren. Representóse en el Corral de Almaguer con licencia del Pe. Confesor" (B. N. Madrid, Ms. 4.051, f. 124). Castrillo, Medinaceli y Peñaranda son desde la época de $D$. Luis de Haro máximos representantes del poder nobiliario. Góngora es el secretario cuya influencia excesiva sobre Haro se censura en varios escritos. No menos conocidos son José González, presidente de Hacienda, y Oyanguren. En el mismo Ms. figuran otros versos en los que se ataca a los mismos políticos tomando como pretexto la aparición de un cometa. A nuestro secretario le correspondió esta quintilla: "De Salamanca la rienda / deste cometa da fin, / pero el hombre no se enmienda; / mas no importa, porque al fin / todo lo paga la Hacienda" (f. 125).

15 Cf., por ejemplo, sarcasmos a propósito de la vanidad "portuguesa" de D. Francisco de Melo en AHN., E, lb. 962, f. 63, etc., o este párrafo de una carta del 29-VI1637: "Dígame V.m. qué se haze de Nicolalde, y si tengo de vivir yo como niño en el limbo, y siempre dependiendo de las voluntades de otros que ni nacieron en mejores pañales que yo ni han leído más años cátreda", ibid., f. 145. 
gestionar la concesión de un hábito de Santiago para su amigo; da cuenta de sus audiencias con el Conde-Duque, que refiere con especial delectación, de su asistencia a las juntas de los Consejos, etc. Noticias más ligeras son las que acompañan, por ejemplo, el envío de unas gacetas y "relaciones" impresas para el Cardenal Infante:

No he avisado a V.m. por menor las fiestas que aquí hubo, porque cada día hemos estado esperando relación de don Antonio de Mendoza; dícenme que está acabada, y la enviaré a V.m. en saliendo, para que la vea Su Alteza.

Aquí va la Gaceta de una [fiesta], en que verá V.m. lindos disparates con que puede reirse un rato. Imprímense de secreto para enviarlas a las Indias.

El Sr. Conde Duque ha pasado esta Semana santa en el Buen Retiro, y en San Gerónimo ha tenido 13 sermones en seis días; yo los he oído todos, y ayer se volvió a Palacio y le vine sirviendo en su coche ${ }^{16}$.

Unos meses más tarde las noticias de Estado se alternan con la narración de un suceso desgraciado a propósito de los trabajos de ornato del Buen Retiro:

Llegaron las estatuas, aunque se había dicho era imposible traerlas desde el puerto donde quedaron hasta Madrid. Pero hasta los bronzes más pesados se mueven a la voluntad de los poderosos (del valido, se escribió primero, tachado).

Parezieron acá muy bien y estimáronse más por lo poco que deste género hay en el Retiro. Hanse puesto en el jardín alto, y desde otro que está mucho más baxo parezen excelentemente. Antes de llevarlas a su sitio, llegó un labrador de una aldea muy vezina a probar sus fuerzas, y levantó buen pedazo la statua de el Sol, y al asentarla cayó, y encima de él la statua, y murió el hombre. ¡Quién dijera que a un villano le había de matar el Sol! ${ }^{17}$

No puede caber mayor frialdad en la apostilla, con pretensiones de agudeza, final. Pero el comentario sobre la insensibilidad de los políticos, aunque sean sólo secretarios, en tanto que lugar común más o menos verificable, quedará para otra ocasión.

Galarreta, por su parte, iba dando noticias puntuales sobre la campaña militar contra holandeses y franceses, los apuros financieros y otros asuntos más domésticos. Llegamos así a una carta del 7 de julio de 1637, donde, en medio de varios párrafos cifrados, escribe lo siguiente:

16 Salamanca a Galarreta, abril de 1637 (AHN, E., lb. 962). El Cardenal Infante debió interesarse en el envío, y Galarreta contestaba: "Las gazetas y demás papeles que V. m. ha imbiado entretienen algo a Su Alteza los ratos ociosos, y me manda diga a V. m. dexe alguna persona de confiança que remita estas bagatelas cuando $\mathrm{V}$. m. estuviere por acá" (6-VI-1637, AHN, ibid.).

17 Salamanca a Galarreta, 6-VII-1637, AHN, E., lb. 962, ff. 131-132. 
De lo que se ofreciere avissaré a V.m. con puntualidad, y por que esta carta no vaya sin pedir algo, suplico a V.m. me haga merced de imbiarme, o traerme, un retrato de medio cuerpo del Conde mi señor, de un pintor que dizen se llama Belázquez o Bázquez; y en esto suplico a V.m. no haya falta, porque lo deseo mucho ${ }^{18}$.

En las minutas de Salamanca no hallamos respuesta a este punto; tal vez la carta, o el párrafo, fue contestada directamente sin necesidad de borrador previo, cosa que sucede con seguridad varias veces en este tomo de correspondencia. Pero no hay duda de que, como pronto veremos, don Miguel no olvidó el encargo y de que "el Conde mi señor" no es otro que Olivares.

Por el momento sobrevienen cambios importantes en la vida de ambos secretarios. Las gestiones del hábito de Santiago para Galarreta no prosperan $y$, por añadidura, éste se enfrenta a la inquietante noticia de que a la corte han llegado acusaciones graves contra su persona: se le imputaba tener demasiada influencia sobre el Cardenal Infante. Si la acusación era falsa, como afirma airadamente el interesado, no podía ser más insidiosa; sobre todo a la luz de lo sucedido pocos años antes, cuando una sospecha análoga motivó el alejamiento de varios nobles y otros miembros de la servidumbre del mismo don Fernando de Austria y de su hermano, don Carlos ${ }^{19}$. Salamanca tranquiliza como puede a su colega y se compromete a parar el golpe. De todos modos, la destitución de Galarreta no tarda en llegar y el llamado a reemplazarlo es, precisamente, el propio Miguel de Salamanca. Situación embarazosa para este, que escribe varias veces asegurando que ha rechazado el puesto; pero las presiones aumentan - dice- y finalmente se ve obligado a aceptarlo. Las relaciones de amistad no se interrumpen por ello: Galarreta siempre había tratado a Salamanca como a su superior y se resignaba al relevo; además, se le daba entera satisfacción de las sospechas anteriores y se prometía situarlo en puesto no inferior al que había desempeñado.

El ascenso de Salamanca no se limitaba a la plaza de Secretario de Estado y Guerra, y no ya interino, del Infante en Flandes; a ese título se añadía la merced de hacerle, cuando volviera a España, miembro del Consejo de Hacienda y la concesión de amplias atribuciones para tratar en los Países Bajos asuntos de finanzas y reclutamientos militares. Ya dispuesto

18 Galarreta a Salamanca, 7-VII-1637, ibid., f. 128 (descifrado en f. 125).

19 Cf. sobre ello G. MARAÑón, El Conde-Duque de Olivares (Madrid: Espasa-Calpe, $1972^{6}$ ), p. 248 y ss., y apéndice XX. Tiene relevancia, a propósito de este asunto una carta muy explícita de Felipe IV que se conserva en copia de letra del secretario Carnero (lo que prueba, si fuera necesario, que Olivares andaba por medio), AHN, E., lb. 865 , ff. $302-303$. 
para el regreso a Bruselas, y con el título de excelencia en su haber, se le encarga además una comisión delicada: aprovechar su paso por París para negociar secretamente con Richelieu una tregua, o la paz definitiva, sin dejar traslucir lo mucho que en Madrid se deseaba alcanzarla.

\section{UN CONFIDENTE AUDAZ, Y DEVOTO}

Miguel de Salamanca sale de Madrid el 13 de abril de 1638 y, según el testimonio de un historiador moderno, "il atteignit Paris le 6 mai, vêtu à la française et parlant tres bien le français, il ne pouvait être reconnu comme espagnol" ${ }^{20}$. En París permanece varios días y tras algunos tanteos a través de intermediarios, consigue entrevistarse con el cardenal. El pretexto formal era agradecerle los pasaportes concedidos para atravesar Francia en plena guerra entre las dos coronas. Una vez que se entró en la "materia reservada", parece ser que a Richelieu le hizo un gran efecto la extraordinaria habilidad del agente del Conde-Duque. Aunque no se llegó a ningún resultado práctico porque ninguno de ellos transigía en las cesiones territoriales en el sur de los Países Bajos, acuerdan mantenerse en comunicación y continuar adelante con los tratos.

Pese a ser infructuosa, la gestión de Salamanca mereció el elogio de Olivares, y don Miguel lo agradece:

Beso los pies de V. E. mil veces por la honra que se sirve de hacerme aprobando el deseo que tuve de acertar a servir a Su Majestad en aquella materia reservada, ya que mi corta capacidad y fortuna no pudieron disponerla como convenía. Vivo con el verdadero reconocimiento de ser hechura de V. E. y con ansia de merecer los honores que se sirve de hacerme ${ }^{21}$.

Ya en Bruselas, el secretario Salamanca inicia una correspondencia permanente con Olivares. La parte conservada ocupa cuatro volúmenes

20 A. LEMAN, Richelieu et Olivares (Lille, 1938), p. 68; el autor dedica todo un capítulo a la negociación de Salamanca. A la documentación francesa manejada en este libro, junto a otros papeles del Archivo de Simancas, ha de añadirse un informe muy amplio del propio Miguel de Salamanca, y varias cartas conservadas en AHN, E., lb. 971. Los tratos del agente español en París adquirieron un aire misterioso al no querer darse un aspecto oficial a las conversaciones: fingidos encuentros casuales en iglesias, disfraces, entradas en palacio al anochecer, etc. Cf. también el artículo del Marqués de Mulhacén, "Una fase de la política secreta del Conde Duque de Olivares. Sus negociaciones secretas con Francia desde 1636 hasta 1642", Las Ciencias, XV (1952), pp. 339-382.

21 Salamanca a Olivares, s. fecha (AHN, E., lb. 971, s. fol.). 
de la colección formada por los papeles del secretario y constituye sin duda el corpus más amplio que existe actualmente de cartas dirigidas al valido por una sola persona ${ }^{22}$. Es difícil exagerar su interés para el conocimiento de la historia militar y política hispano-flamenca en el periodo de la guerra de los Treinta años que cubren estas cartas; aquí, sin embargo, nos ocuparemos sólo de los aspectos más personales.

La confianza que Olivares tenía en Salamanca parece traducirse a veces en cierta intimidad. El secretario podía permitirse censurar -comedidamente- personas y conductas ajenas, sabiendo que se le hacía caso; podía, también, recomendar a su protector la lectura de ciertos libros, sobre todo de plantas de fortalezas y de cartografía (una afición constante en el Conde Duque), y enviárselos:

Envío a V.E. un libro, que si no ha llegado por allá hasta ahora parecerá muy bueno, de plantas de las plazas de Francia, que aunque no tienen penipié son muy bien hechas. Han recogido estos libros no habiendo reparado a la impresión el inconveniente que les tenía ${ }^{23}$.

Remito a V.E. las cartas del país de Grisones, del autor que hizo el de las plazas de Francia, y creo no le habrá allá. También envío a V.E. tres o cuatro libricos nuevos que acaban de imprimirse en Holanda. Ahora ha salido otro Mercator que tiene 100 cartas más que el Blao; si V.E. es servido le enviaré, y el de todas las ciudades del Mundo, de nueva impresión, si V.E. no le tiene de la pasada; lo mismo es una que otra ${ }^{24}$.

Las cartas del secretario, de quince y más folios muchas veces, permiten seguir de cerca todos los asuntos importantes de la política y la mar-

22 AHN, E., libros 971 (1638-1639), 959 (1640), 969 (1641), y 970 (1642-1643), todos ellos con las minutas de cartas de Salamanca al Conde Duque. Las respuestas de Olivares se conservan sólo en parte, algunas en el lb. 955, y otras dispersas en distintos volúmenes. En los cuatro libros citados, ocasionalmente se han encuadernado también algunas minutas de cartas dirigidas al rey y al secretario Andrés de Rozas, en las que se tratan asuntos relacionados con el contenido de las cartas dirigidas a Olivares. La mayoría de las minutas son de letra de Pedro Fernández del Campo, oficial de la Secretaría de Estado cuyo ascenso a puestos de la mayor importancia tiene lugar a partir de su asistencia al congreso de Münster, y destacará sobre todo en la minoría de Carlos II. Estos libros, como todos los de Miguel de Salamanca, están encuadernados en orden cronológico inverso; lo que en las cartas originales había de ir en cifra se indica en las minutas por medio de subrayados o con lineas longitudinales en la página.

23 Salamanca a Olivares, 21-XII-1638 (AHN, E., lb. 971, s. fol.).

24 Salamanca a Olivares, 25-II-1639 (AHN, E., lb. 971, s. fol.). Tachado desde abora ha salido. Sobre la biblioteca de Olivares y su interés, estratégico, por los mapas, cf. G. MARAÑón, op. cit, p. 160 y ss., y apéndice XI. 
cha de la guerra en Flandes y el Imperio. Bajo la forma de humildes sugerencias o comentarios al vuelo, Salamanca proporcionaba, en realidad, al valido de Felipe IV informes muy precisos sobre decisiones de alto alcance que habían de tomarse a corto o medio plazo. Aunque pueda parecer exageración, tras leer esta correspondencia es posible afirmar que el secretario Salamanca fue en estos años uno de los principales inspiradores de buena parte de la política exterior de Olivares. Dado el aprecio que de sus noticias y opiniones se tenía en Madrid, don Miguel llegó incluso a establecer una vía particular de comunicación más rápida y segura, al margen del correo ordinario, para hacer llegar sus cartas al Conde Duque por medio de mercaderes portugueses afincados en Rouen y París, corresponsales de un asentista, portugués también, que residía en la corte de España ${ }^{25}$.

Olivares, por su parte, no podía tener mejor opinión de su colaborador y hombre de confianza. Así lo muestra, por ejemplo, en una dramática consulta del Consejo de Estado en 1640, año que -son sus palabras- "se puede contar sin duda por el más infeliz que esta Monarquía ha alcanzado, a lo menos después que yo tengo uso de razón". Nunca, sigue diciendo, se habían hecho tantas prevenciones de dinero y armas, y nunca los resultados habían sido tan desastrosos. Pero lo peor no era perder batallas o territorios, sino la falta de "cabezas", estribillo este bien conocido en el Conde Duque. Y sin embargo, en lo que concierne a Flandes hará una excepción:

Hallo a Flandes con mayor necesidad hoy de reparo en esta parte, porque el señor Infante se halla para el consejo, que es lo primero o el todo, con solo el presidente Roose, don Felipe de Silva y don Miguel de Salamanca (y, hablando con precisión, con solo este postrero). Es menester más y más, aun cuando no pudiera temerse la falta de salud y vida de don Miguel, tanto más fácil cuanto más trabajada ${ }^{26}$.

En efecto, la salud del secretario era escasa - como él mismo se encargará de recordar con frecuencia-, y sorprende que una persona que gozaba de tanto aprecio se viese obligado por el protocolo a sobrellevar, pese a sus achaques, las largas horas de despacho con el Cardenal Infan-

25 El asentista es Paulo Saravia, bien conocido como testigo acusador en el proceso por judaizante que sufrió Juan Núñez de Saravia, cf. J. CARo BAROJA, Los judios en la España moderna y contemporánea (Madrid, 1960), II, p. 62. Sus corresponsales de París y Rouen eran, respectivamente, Juan Luis Guimaraes y Diego Pereda. Fue el propio Olivares quien sugirió al secretario utilizar los servicios de estas personas (cf. AHN, E., lb. 971, s. f.)

26 AHN, E., lg. 674, s. fol. 
te permaneciendo siempre de rodillas, mientras negociaba o escribía. Como una gran merced, el rey aconseja a su hermano que se permitiera al secretario disponer de un banquillo, y para ello había que invocar precedentes de la época de Felipe II ${ }^{27}$. Aun así el beneficiario prefirió (y no dice por qué) no hacer uso del favor, y escribirá a su paisano y mentor, Andrés de Rozas, preocupado por si tenía o no que agradecer al rey una merced que no había tenido efecto ${ }^{28}$.

Pero volvamos ya al cuadro de Velázquez. O cuadros.

\section{RETRATOS EN CADENA}

Tras su entrevista con Richelieu, y a las pocas semanas de su llegada a Bruselas, Salamanca escribe al Conde Duque con noticias del estado en que ha hallado los asuntos en Flandes. Lo primero que hace es informar de un contratiempo para el buen desempeño de sus funciones de secretario que se apresura a relatar a su patrón:

Para muchas cosas que traía que hacer de el servicio de Su Majestad me hacen gran falta los papeles que venían con mi ropa, la cual me embarazó en Vitoria un alcalde de sacas, con pretesto de que se había pasado el término dos días de una cédula de Su Majestad en que me hacía merced de dar licencia para sacar 100 marcos de plata labrada, de la cual aun no traía 10 . Y esta dilación fue causa de que la ropa no alcanzase la embarcación de mis criados, con que juzgo se podía haber perdido; y tiéneme con sumo cuidado porque venían papeles de consideración y algunas órdenes de Su Majestad, y memorias de algunas cosas que tendría inconveniente perderse, en que no he tenido culpa y se puede atribuir a la demasiada justificación del alcalde de sacas. $\mathrm{Y}$ assí no he podido tratar aquí otra cosa que la de la Caballería [...]

Entre las cosas que con la ropa quedaron fue el retrato de V. E., que me ha dado gran pesadumbre, y he faltado de cumplir la palabra que di de embiar una copia a aquella persona con quien se trató la materia reservada ${ }^{29}$.

27 "Aquí me han dicho que con la falta de salud y vista que tiene Don Miguel de Salamanca, es preciso que trabaje demasiado leyendo y negociando con vos de rodillas tantas horas como ha menester el despacho. $Y$ porque creo que os servirá mucho si está bueno, por ser sujeto de aventajadas partes, parece conveniente aliviarle; y así, a título de flaco y indispuesto seguiréis los ejemplos que hay, y entre otros el del señor rey Don Phelipe segundo nuestro abuelo, y le mandaréis que use de algún banquillo para despachar con vos; y en la parte de leer os valdréis de Martín de Inarra, salvo en lo reservado, con que podrá correr el despacho con mayor brevedad y continuación" (Felipe IV al Cardenal Infante, 26-V-1639, AHN. E., lb. 955, s. fol.).

28 Salamanca a Rozas, 31-VIII-1639 (AHN, E., lb. 971, s. fol.).

29 Salamanca a Olivares, 22-VII-1638 (AHN, E., lb. 971, s. fol.). 
La persona "con quien se trató la materia reservada" es, como sabemos, Richelieu; y ello quiere decir que mientras españoles y franceses arrastraban una guerra abierta desde hacía cuatro años, los directores de sus respectivas políticas se intercambiaban cortésmente sus retratos ${ }^{30}$. Aunque no quiso darse publicidad al hecho, el cambio de retratos fue tratado en el Consejo de Estado unos meses después de que Salamanca lo ajustase en París. A. Leman reconstruye la historia a partir de la documentación conservada en París y Simancas: "Le 29 juillet [1638] Chavigny promettait d'envoyer son portrait qu'il faisait faire à Paris. Le 17 novembre, Salamanca mandait que Richelieu désirait le portrait d'Olivares et enverrait le sien ensuite [...] Le Conseil d'Etat aprouve qu'Olivares envoyat son portrait" ${ }^{31}$.

Al parecer, la carta del secretario que se vio en el Consejo no especificaba quién era el autor del retrato de Olivares que directa o indirectamente se pensaba hacer llegar a Richelieu. El detalle sí consta, en cambio, en la minuta o borrador de la misma carta, aunque se indica que el párrafo había de escribirse en cifra:

Cuando llegué aquí [Bruselas] embié un Retratico pequeño, con talcos, de Madama de Combalet; no he sabido si se perdió, y. en teniendo noticia de que llegó allá, embiaré a V. E. el grande, que le he guardado para embiar más copias. No creerá V. E. la instancia que el secretario Boutillier haze conmigo por un retrato de V. E., y como no ha llegado el que me hizo Diego Velázquez no he podido embiársele. Y dize me tiene prevenido uno del señor Cardenal, hecho de un gran pintor, pero que no me le remitirá hasta tener el de V.E. ${ }^{32}$.

Como se advierte, Salamanca suponía a su amo interesado por la vida familiar —o frívola, según otras versiones- de Richelieu; y además de Olivares debía haber en Madrid, a juzgar por las copias que se anuncian, otras personas deseosas de conocer en pintura la belleza de la célebre Madame. El intercambio de retratos que aquí nos interesa, sin embargo, no podía por el momento relizarse: Richelieu quería tener en su poder el del Conde-Duque antes de enviar el suyo, pintado por un "gran pintor"

30 Mucho es lo que se ha escrito acerca de la emulación obsesiva de Olivares hacia Richelieu (Cf. ya G. MARAÑón, op. cit., pp. 310-311); pero de las cartas que luego se transcriben, y de otras fuentes, puede deducirse que no era inferior el interés personal del político francés por su rival.

31 A LEMAN, op. cit., p. 74, con referencias a una carta de Salamanca del 17-XI1638, vista en consulta del Consejo de Estado del 5-I-1639 (AGS, E., 2054).

32 Salamanca a Olivares, 17-XI-1638 (AHN, E., lb. 971, s. fol.). El "secretario Boutillier" es Claude le Boutiller, conde de Chavigny, bien conocido como colaborador estrecho del Cardenal. 
que no se especifica, pero el celo excesivo del alcalde alavés había impedido que el cuadro de Velázquez llegase a Flandes. Cuando después de varios meses de dilación por fin se le da curso, ocurre otro incidente que parece arruinar del todo, o diferirlo sine die, el canje de cortesía. El secretario se apresura a comunicarlo:

$\mathrm{Al}$ correo que trajo estas cartas desbalijaron tres leguas de Cambray, y le tomaron el retrato de V. E. que me traía, que era el mejor que había hecho Diego Belázquez, que dexé en España para que le inviasen con otras cosas. Suplico a V. E. le mande que me haga otro. Papeles no he echado menos hasta ahora ningunos 33

Recapitulemos un poco:

1. Galarreta, en julio de 1637 , pedía a su colega que le enviase un retrato del Conde Duque, de medio cuerpo, pintado por Velázquez, y recalca que 'lo desea mucho'. Su carta parece indicar que el retrato, o el "modelo" del retrato, ya existía, y en ese caso conocería su existencia por informes ajenos, puesto que llevaba varios años fuera de España. Menos probable es que, sorprendido de improviso por la fama del pintor - del que desconocía su nombre exacto: "dicen se llama Belázquez o Bázquez"-, le entrasen deseos de poseer un retrato nuevo del valido pintado por su mano. Es de suponer que Salamanca complacería a su amigo, y más al haber fracasado en la gestión de otros intereses más vitales para este. Aunque poco después Galarreta pierde su empleo como secretario de Estado del Infante, no ha caído en desgracia; se le prometen otros puestos ${ }^{34}$, en los que el cuadro seguiría teniendo la misma función, suntuaria y de manifestación de lealtad y devoción hacia el hombre de quien confesaba ser "hechura". Sea como fuere, Galarreta sale de Flandes nada más llegar Salamanca ${ }^{35}$, y la pintura, si estaba en su poder, sería trasladada a España con el resto de su equipaje, dado que su regreso era, por el momento, definitivo.

2. Salamanca escribe desde Bruselas - julio de 1638- que un retrato del Conde Duque que traía le ha sido retenido en Vitoria junto con el

33 Salamanca a Olivares, 12-V-1639 (AHN, E., lb. 971, s. fol.).

34 Cf. carta de Felipe IV a Salamanca, AHN, E., lb. 961.

35 "El secretario Francisco de Galarreta ha partido a Inglaterra para pasar a España, en conformidad del orden que tuvo de V. Majestad. Del celo con que ha procurado servir a V. Majestad en la ocupación que ha estado a su cargo he hallado muy buena relación (seguia, tachado: El puesto está sujeto a la censura de muchos, pero dará entera satisfacción de su proceder)". Salamanca a Felipe IV, 5-VI-1638 (AHN, E., lb. 971 , s. fol.).p 
resto de su equipaje. En noviembre especifica que el cuadro es "el que me hizo Diego Velázquez" y que sigue sin haberlo recibido. Al afirmar que el cuadro era suyo queda claro que no se trata del mismo encargado por Galarreta. Puede conjeturarse que al concertar con el pintor el cuadro para su amigo le entraron deseos de adquirir otro para sí mismo. Ello se confirma porque el retrato era, en su opinión, "el mejor que había hecho Diego Belázquez".

3. Sabemos, por otra parte, que a raíz de su entrevista con Richelieu en París, Salamanca había acordado enviarle una copia del original que él poseía. Para ello esperaba con impaciencia la llegada de su cuadro; la copia se haría, naturalmente, en Bruselas y sería ejecutada por un artista flamenco o establecido en Flandes.

4. Por último, al saber que el correo, que por fin había llegado a las fronteras de Flandes con el retrato, ha sido desvalijado por soldados franceses, el secretario da por perdido el cuadro y pide a Olivares - mayo de 1639- que mande (es el verbo que emplea) al pintor que le haga otro. El Conde-Duque, obviamente interesado en cumplir el ofrecimiento hecho al Cardenal, no dilataría la orden.

He aquí un cuadro real transformado en cuatro posibles, o también reales. Sobre todo teniendo en cuenta que el retrato considerado perdido reaparece. Al darle al privado la noticia, alegre por una vez, de la gran victoria obtenida en junio de 1639 por el general Piccolomini en Thionville, el secretario no olvida señalar el buen augurio que le había supuesto saber, pocas horas antes de la batalla, la recuperación del cuadro:

También despacho este correo por tierra, y avísase por otras partes para que antes tenga V. E. este alivio de tanto trabajo como le cuesta la disposición de estos sucesos. Y no puedo menos de decir a V. E. que esta mañana me envió el conde de Fuensaldaña el retrato de V. E. que habían tomado en Francia al correo, que le restituyeron, y me confirmó esperar una nueva muy feliz, y así ha sucedido ${ }^{36}$.

Ahora se podría hacer, por fin, la copia para Richelieu. Los acontecimientos que siguen a la victoria de Thionville no fueron tan felices (incluyendo la pérdida de Hesdin y el desastre naval en las "Dunas"), y las minutas de cartas de Salamanca, posteriores a la que hemos transcrito se ocupan sólo de asuntos de Estado. No obstante, los intentos subterráneos de hacer la paz con Francia no llegaron, formalmente, a interrumpirse en ningún momento; y de ello puede deducirse que el ofrecimiento de enviar la copia del retrato seguía en pie. Que el canje se llevó finalmente a

36 Salamanca a Olivares, 11-VI-1639 (AHN, E., lb. 971, s. fol.). 
término es lo que puede deducirse de una nueva referencia al envío de obras de arte que se halla en la correspondencia de Salamanca a Olivares, Más de un año después de la última alusión a los retratos del valido, el secretario daba cuenta así de una nueva gestión pictórica:

Embío a V. E. con este correo el retrato de la Sra. Reyna de Francia y del Delfín en una pintura, que me la ha dado la sra. duquesa de Chevrosa ${ }^{37}$.

La guerra entre España y Francia continuaba con violencia creciente, pero ello no era obstáculo al interés de la corte de Madrid por hacerse con los retratos de la familia real francesa, estrechamente emparentada con la española. Al no aludirse en esa carta $-\mathrm{y}$ hubiera sido el momento oportuno- al retrato de Olivares destinado a Richelieu podrá darse por sobreentendido que el canje se había realizado ya.

En cuanto al nuevo cuadro original encargado a Velázquez para sustituir al que se creía perdido, no hemos hallado otras referencias en los papeles de Salamanca. En cualquier caso, ya era tarde para dar contraorden; y si el cuadro - como parece lo más probable- efectivamente llegó a pintarse, hallaría rápida salida, vista la demanda de retratos de Don Gaspar que existía entre secretarios y otro tipo de personas. En suma, es muy verosímil que los retratos del Conde-Duque, originales de Velázquez o -en un casocopia directa, surgidos a partir de la lejana petición de Galarreta fueran efectivamente cuatro. Veamos cuáles pudieron, o pueden, ser.

\section{IDENTIFICACIONES PROBLEMÁTICAS}

La indicación facilitada por Galarreta de que el retrato que pide es "de medio cuerpo" y la fecha de su carta (7 de julio, 1637) delimitan bien los cuadros de que podía tratarse en esta correspondencia flamenca. Bustos de Olivares, adscritos a Velázquez y su taller, como originales o copias, parecen conocerse sólo los seis que se describen en el Catálogo de López-Rey (núms. 511-516) ${ }^{38}$. Las dimensiones de tres de ellos son muy similares, en torno a $67 \times 55 \mathrm{~cm} .{ }^{39}$, y se da por supuesto que a partir de

37 Salamanca a Olivares, Diciembre 1640 (AHN, E., lb. 959, s. fol.).

38 J. LÓPEZ-REY, Velázquez: A Catalogue Raisonné of his Oeuvre (London: Faber \& Faber, 1963).

39 El núm. 511 (Hermitage, lám. 90): 0’67 × 0'545; el 513 (actual paradero desconocido, olim col. R. Ford, lám. 379): 0'67 × 0'57; el 512 (Metropolitan, lám. 378): 0'688 × 0'533. De los tres restantes hay uno (el núm. 514, Linz, lám. 380) del que no se indica el tamaño; los otros sobrepasan o reducen sensiblemente, pero sin exceso, 
uno de ellos, el de Leningrado (511), se hizo "ex archetypo Velázquez" en 1638 un grabado, obra de Pannels, y otros dos no fechados ${ }^{40}$.

Dos de estos cuadros - los de Leningrado y Dresde (511 y 515)forman pareja, a pesar de las diferencias de tamaño. La cabeza, sobre todo, es muy similar; y Marañón, que consideraba al segundo como réplica, los agrupa bajo la denominación de variedad "eufórica". En ese sentido podrían sumárseles también el de Linz (514) y uno de los actualmente no localizados (516), al parecer bastante inferiores. El retrato del Metropolitan (512), descrito gráficamente por Marañón como variedad melancólica o "espectral", hace par, a su vez, con el que perteneció a Richard Ford (513).

Acaso sorprenda el hecho de que todos esos cuadros han visto alguna vez negada, o discutida, su autoría velazqueña por unos u otros críticos. Incluso del de Leningrado, el más "seguro" según la aceptación general, dudaba Mayer que fuese obra del maestro. López-Rey considera como obras "de escuela" cuatro de ellos, y otro -el de Dresde- como fragmento de un "trabajo de estudio". Los juicios contrarios a la autoría velazqueña de estos retratos parecen haberse impuesto definitivamente entre los especialistas, y en las últimas obras de conjunto sobre el pintor sevillano sólo se hace referencia, si se hace, al cuadro de Leningrado ${ }^{41}$. [Ello no es ajeno a que en la última $-\mathrm{y}$ tan lamentable, por motivos diversos- exposición dedicada a Velázquez en el Prado no figurase ni uno solo de los retratos de Olivares de medio cuerpol.

Hasta ahí los historiadores del arte, que no siempre explican de forma inteligible (o de forma alguna) las razones de sus seguridades, negadoras o afirmativas, y de sus dudas. Pero ya hemos visto, sin embargo, que Velázquez pintó por sí mismo con casi total seguridad tres retratos de medio cuerpo del Conde Duque. No parece que haya duda en el caso de los que poseyeron los dos secretarios; y el que se pintó para

el modelo representado por los tres primeros: el núm. 515 (Dresde, lám. 377) mide 0'92 $\times 0$ 0'74, y el núm. 514 (paradero actual desconocido, olim col. del Marqués de Salamanca, lám. 381), 0’45 × 0’42.

40 También se inspira en el retrato del Hermitage una miniatura del Palacio Real de Madrid, G. MARAÑón, op. cit. (fig. 26). Marañón reproduce igualmente el grabado de Pannels (fig. 22), que puede verse también en el catálogo de López-Rey, así como otro de los grabados, atribuido alguna vez al mismo Velázquez (lám. 382).

41 En realidad, las negaciones vienen de muy atrás. Uno de los primeros estudiosos de la obra velazqueña indicaba ya: "Es indudable que Velázquez habría hecho más de un retrato del de Olivares antes y después del de Fuenterrabía, pero de esto a suponer originales de su mano cuantos por ahí andan en poder de aficionados y galerías, hay un abismo", G. CRUZADA-VILlAAmIL, Anales de la vida y de las obras de Diego de Silva y Velázquez, escritos con ayuda de nuevos documentos (Madrid, 1885), p. 120. 
sustituir al robado, y temporalmente perdido, en Cambray puede presumirse que también era de mano del maestro, sobre todo si se atiende a que Miguel de Salamanca se refiere expresamente al pintor de cámara en su carta al Conde-Duque. Cabe agregar también que Olivares tenía la vanidad suficiente como para ordenar que el retrato que había de servir de original en Flandes no fuese una copia.

Claro está, sin embargo, que el que Velázquez pintara tres retratos no significa que se hayan conservado, ni que deban ser identificados con los bustos del Conde-Duque que hoy existen. Si personajes relativamente oscuros como Galarreta y Miguel de Salamanca podían sin gran dificultad obtener del pintor un retrato de Olivares, un "original" en su caso por haber aprovechado el momento, habría también varios otros cortesanos que por las mismas razones que ellos desearían tener el suyo. Estos cuadros, de escaso tamaño, fáciles de desplazar y muy a propósito para ser mostrados en el escritorio o el salón del burócrata agradecido, más o menos adulador, manifestaban el poder, por delegación, de quien podía exhibir una prueba de su cercanía al omnipotente valido. Los cuadros podían hacerse en serie, visto el éxito, y las copias debieron proliferar. Las que hoy existen son con seguridad sólo una parte de las muchas que se hicieron; pero no cualquier pintor podía permitirse reproducir la efigie de don Gaspar. Queda en pie, en cualquier caso, el hecho de que también Velázquez, en esta ocasión, se reprodujo a sí mismo. Precisar más es tarea de los expertos en el uso de los medios técnicos y estilísticos que se supone que debieran permitir dilucidar ese tipo de cuestiones, aunque los profanos podamos también manifestar nuestro escepticismo sobre la validez de tales medios, o incluso sobre el propio concepto de "autoría" que suele manejarse.

Un medio auxiliar que suele ser útil, definitivo en ocasiones, consiste en rastrear los primitivos propietarios y emplazamientos de las telas de identificación insegura. En el caso de los bustos de Olivares sólo se conoce a los más recientes, o ni aún eso. El retrato que se muestra hoy en en el Metropolitan perteneció a Godoy; el de Leningrado fue adquirido por el Zar Alejandro en 1815; otros fueron comprados en Madrid en fechas más o menos antiguas e inciertas. Desconocemos también si al regresar de Flandes a España, en 1648, don Miguel trajo o no su cuadro. En el intervalo habían sucedido demasiados acontecimientos, y entre ellos la caída en desgracia y la muerte de su protector. Salamanca supo adaptarse bien al cambio, y los nuevos gobernantes (Haro, Castrillo, etc.) siguieron apoyando su ascenso. El mismo don Miguel, o su amanuense, podía rotular los antiguos cartapacios de su correspondencia con Olivares con títulos como "Minutas de cartas del sr. Don Miguel de los años 1636 
y 1637, para el conde de Olivares, que era en esos años ministro y privado de Su Majestad", distanciándose, como si ese conde de Olivares se tratara de alguien distinto del personaje a quien Salamanca lo debía todo. Es claro que poseer un retrato del Conde-Duque después de 1643 era muy distinto, como símbolo, a haberlo poseído antes. El cuadro pasaría a significar algo enojoso y molesto para su propietario, y con tanta más razón si este seguía haciendo carrera a la sombra de quienes habían derribado al anterior amo. Aquellos retratos, originales o copias, que hasta entonces ocupaban un lugar preferente en el escritorio o el salón serían arrinconados, o incluso destruidos ${ }^{42}$. Pudiera ser que también Miguel de Salamanca se deshiciera de su Velázquez, que lo dejase en Flandes y que..., sigamos la hipótesis, ese retrato fuera el mismo que hoy cuelga en el Hermitage - uno de los dos hoy existentes de los cuales no consta su presencia en España en fecha antigua-. Sería curioso entonces comprobar, a la vuelta de tres siglos, la coincidencia de las opiniones del secretario Salamanca, que tenía a su retrato por "el mejor" que había pintado Velázquez, y del doctor Marañón, de quien es sabido lo mucho que admiraba el cuadro de Leningrado.

Hasta aquí la lucubración más o menos aventurada si se quiere, pero no mucho más que las que a veces sirven para fundamentar los juicios de los 'expertos'. Las cartas de nuestros secretarios permiten, en cambio, afinar más, y con plena seguridad, la fecha del retrato arquetipo y sus derivados. El grabado de Pannels, fechado en Madrid en 1638, daba ese año como límite y en él se data el busto de Olivares en las cronologías velazqueñas a partir de Allende-Salazar. A la luz de lo que escribe Galarreta, puede precisarse más la fecha de la composición y adelantarla, al menos, a principios del año anterior. Si en Flandes conocía la existencia del retrato ya en julio de 1637 habrá que descontar el tiempo que tardaban los correos ordinarios, un mes y medio, y el que mediase hasta que su corresponsal le informó de la existencia del cuadro, y de su autor, el pintor "que dizen se llama Belázquez o Bázquez". El original que llevaba a Bruselas Miguel de Salamanca es también de 1637; los otros dos - original y copia - serían ya de 1639. En fechas intermedias y posteriores se situarán varias otras copias para el consumo de nobles adictos al

42 En el inventario de las pinturas que poseía el pintor Domingo Guerra Coronel en 1652 figura "un retrato del Conde de Olivares, de tres cuartos de alto, con su moldura negra". Es, y con diferencia, el que alcanzó el precio más bajo en la tasación hecha por Nardi y Mazo de la veintena de obras relacionadas: 33 reales, cantidad ridícula comparada con los 1000 que alcanzó un desnudo de Velázquez, con los 400 de un San Francisco y un San Jenaro, o los 500 en que se valoró una lámina del Prendimiento de Cristo. Cf. Varia Velazqueña, II (Madrid, 1960), pp. 282-283. 
ministro y burócratas en estado de merecer. A la serie pudo pertenecer, por ejemplo, el que poseyó el historiador y genealogista Rodrigo Méndez Silva. Como lo recuerda Caro Baroja:

Méndez Silva murió como judío público, al parecer, en Venecia. Pero en Madrid quedó su casa, con su biblioteca, sus muebles, con sus cuadros; y entre los cuadros aparecen, al tiempo de la subasta, un retrato del Conde-Duque de Olivares y dos de unos enanos... Asuntos de porte más velazqueño no pueden darse ${ }^{43}$.

Después de 1643 podrán hacerse otras copias, pero su función será ya muy distinta: la de piezas deliberadamente históricas, de museo; o incluso la de falsificación planeada como tal. Claro está que Velázquez, el pintor de la cámara regia, no pudo ser el autor de ningún retrato del valido que se pintase después de la caída en desgracia de su antiguo protector.

Cabría trazar un paralelo, por poco exacto que sea, con lo que sucede en la literatura coetánea. Así a propósito, por ejemplo, de la transmisión de la obra de Quevedo. El éxito y la fama del escritor, suscitan, ya en vida de éste, la aparición de imitadores de muy distinta laya. Unos se conforman con el papel de imitadores, pero otros aspiran a que la imitación pase por obra del maestro: la dejan anónima o la ponen sin más a su nombre. Súmese que el propio autor no siempre admitirá la paternidad de lo escrito, o que podrá introducir modificaciones que van desde el simple retoque a la refundición radical; pero la nueva redacción no anula la transmisión de la versión o versiones anteriores. Los lectores contribuyen también a la confusión; son muchos los que desean hacerse con las obras no impresas del escritor; se buscan autógrafos o copias antiguas y los manuscritos se copian una y otra vez; una vez introducida una atribución, por disparatada que sea, será difícil descabalgarla del ilusorio canon que la transmisión va estableciendo. En algunos de los curiosos o aficionados existirá a veces una intención depuradora de separar lo inauténtico; pero en otros puede más el deseo de alimentar la leyenda del escritor chocarrero, la del mártir perseguido por la malevolencia y la estolidez de los poderosos, o cualquier otra. Se dejan rodar falsificaciones antiguas o se da curso a otras nuevas. Pueden forjarse entonces escritos tan peregrinos y obtusos como unas cartas del inquisidor Adam de la Parra, compañero de persecuciones de Quevedo, que empiezan nada menos que con un "Querido Paco".

En nuestros días la crítica filológica, como la de Arte, intenta establecer el corpus auténtico de la obra del autor y eliminar la ganga, cosa nada fácil cuando el crítico se enfrenta a imitaciones más antiguas y menos

43 J. Caro Baroja, art. de 1963, cit. infra, p. 226. 
burdas, o a redacciones divergentes de textos próximos. Se ponen a contribución métodos muy refinados de colación de textos, análisis estilísticos, etc., con resultados positivos..., a veces. Lo que continúa siendo problemático o insoluble es mucho, y el filólogo reconoce la imposibilidad de determinar con absoluta certeza el canon de la obra auténtica del autor; por lo mismo le sorprende que en la crítica de arte se actúe tantas veces con una aparente y dogmática seguridad que se revela ilusoria tan pronto como se confrontan seguridades y dogmatismos de distinto signo. Por otra parte, hay que admitir que el valor histórico-cultural de una falsificación antigua, realizada con los mismos métodos, técnicas e intenciones, no es inferior al de la obra probadamente auténtica. Al menos, así sucede en varios casos; y es el propio concepto de la originalidad o de la autoría individual lo que se revela inoperante para entender el significado de varias creaciones, literarias o pictóricas, del siglo XvII.

\section{Pragmática. Del Clientelismo a la magia}

Volviendo, para terminar, a Morris y su pragmática del objeto artístico, se advierte que las alusiones en las cartas de los secretarios aquí transcritas proporcionan una información nada despreciable sobre las "causas, usos y efectos" que tuvieron los cuadros a que se referían.

Objeto suntuario, símbolo de adhesión de quienes se confiesan "hechuras" y "esclavos" del valido, o muestra de que se disfruta de su protección, el retrato de Olivares era para estos burócratas servidores de la pluma algo muy semejante a lo que los retratos de personajes poderosos han seguido siendo hasta nuestra época. La analogía puede advertirse, incluso, en el todavía rudimentario proceso de repetición en serie. La litografía, el cromo y la reproducción fotográfica se encargarán más tarde de proporcionar al símbolo un carácter más oficial y menos personalizado, y de hacerle perder, de paso, el valor suntuario y artístico.

Siempre dentro de lo simbólico, es fácil también advertir un uso, y un efecto, diplomático, de intercambio de buena voluntad aparente. Los retratos se donan o truecan como muestra de la disposición amistosa entre contrincantes que dicen querer dejar de serlo. Parece que esta entrega de la propia imagen al enemigo, a cuyo arbitrio queda, cabe interpretarla como la manifestación de un ponerse a su merced y mostrar la falta de dobles intenciones. Sabemos bien que en el plano de la realidad, esto era falso en gran medida, y por ambas partes, en el caso que aquí nos ocupa.

Un "efecto" más anómalo del retrato es el que está explícito en la última carta del secretario Salamanca. Dice éste que haberlo recuperado fue para 
él la confirmación de esperar una noticia feliz en vísperas de la batalla, y que así sucedió en efecto pocas horas más tarde. ¿Una adulación más al privado? Sin duda, pero uno no sabe qué pensar al advertir que de una manera casi mecánica Don Miguel consignaba con exactitud las coincidencias "causales" que se daban entre la fecha de un encuentro militar victorioso o de la toma o recuperación de una plaza fuerte, por una parte, y, por otra, la festividad o víspera de los santos patronos de la ciudad en cuestión o de otros fastos del calendario reverencial hispánico, del nombre del maestre de campo, o de otras circunstancias no menos "irracionales" y que, naturalmente, no se mencionan para nada cuando la batalla o la plaza se pierden. Ello puede sorprendernos en pleno siglo XVII, y más aún por parte de un Don Miguel de Salamanca que supo revelarse como político frío, ilustrado, y buen conocedor de los requisitos bien materiales ("danari e più danari") de los que dependía el resultado de la guerra. Súmese, además, que en el caso del retrato de Olivares tomado como augurio profético no cabe una motivación religiosa. Pero nada de ello obsta para que veamos aquí la manifestación de una forma de mentalidad mágica, muy viva en en el siglo XVII, y no sólo entre las clases inferiores. En un libro espléndido, Vidas mágicas e Inquisición, recuerda Julio Caro Baroja los célebres hechizos, profecías y demás fenómenos sobrenaturales en que se vieron envueltos, tomando incluso una parte activa, Olivares y el mismo Felipe IV. También en la corte de Luis XIII y Richelieu se daba fe a los astrólogos; en las actividades de uno de ellos aparece mezclado junto al Cardenal el mismo Chavigny a quien hemos visto antes como intermediario en el canje de retratos ${ }^{44}$.

El papel del pintor en medio del tráfago a que se vieron sometidos los retratos del Conde Duque aparece muy difuminado. Es claro que lo que interesaba más a las personas que intervinieron en la ejecución y traslados de la efigie del valido es el cuadro como objeto y lo que representa la persona retratada. Hay, desde luego, un cierto reconocimiento de la fama como artista que ya tenía Velázquez y de lo que se apreciaban sus obras ${ }^{45}$. Pero junto a ello se advierte, por ejemplo, que los secretarios no le conceden el

\footnotetext{
${ }^{44}$ J. CARO BAROJA, Vidas mágicas e Inquisición (Madrid, 1967), I, cap. iv; II, p. 171.

45 Reconocimiento tardío, en 1637, como se ha visto, en el caso de Galarreta ("un pintor que dizen se llama Belázquez"), pues Velázquez era pintor real desde 1623. Pero a todo hay quien gane. El Cardenal de la Cueva en carta de 1649 escrita en Roma dice: "Aquí ha venido un tal Velázquez, ayuda de cámara del Rey, y dice que con comisión de andar por Italia viendo estatuas y pinturas", y se hace eco de los que murmuraban "deziendo que no es a propósito del tiempo que corre [...] el ocupar el tiempo y dinero en cosa de tan poca sustancia". El Cardenal remacha el clavo unas semanas después: "Muy vengonzosamente se habla en la comisión de estafa de pinturas y estatuas que se dio al ayuda de cámara Velázquez". Cf. J. M. PITA ANDRADE, "Noticias
} 
tratamiento de don, frontera importante en la época y que sólo traspasó pocos meses antes de su muerte; o que estimaban su labor como cosa próxima a lo simplemente artesanal. Para el hombre moderno imbuído de una idea reverencial del arte sería sumamente desmitificador, si hechos análogos no fueran de sobra conocidos, ver que un Miguel de Salamanca tan completamente borrado de nuestra memoria escribía, con otra fraseología, lo que hemos leído: 'Se me ha perdido el cuadro de Velázquez; mándele usted que me pinte otro igual'. En el gran artista coexiste un funcionario no muy distinto de los Galarreta y los Salamanca, un servidor voluntariamente subordinado a los deseos y órdenes del poderoso y en espera de obtener su ascenso por los pasos contados. De esa faceta menos aireada del pintor Velázquez, de su personalidad "de hombre pulcro, recatado, cortesano, deseoso de servir a su rey y de alcanzar honores por la vía que entonces se alcanzaban", así como de sus "silencios" ante una sociedad terrible que se refleja sólo muy parcialmente en sus cuadros, se ha ocupado Caro Baroja en un breve y sustancioso artículo ${ }^{46}$. No vamos a glosarlo aquí.

[Pero no sería del todo innecesario tratar de extraer algunas consecuencias de datos que son bien conocidos hace tiempo. Por ejemplo, los que atañen al status del artista y sus funciones, empezando por la escueta orden del nombramiento: "A Diego Velázquez, pintor, he mandado recibir en mi servicio para que se ocupe en lo que se le ordenare de su profesión y le he señalado veinte escudos de salario al mes" (6-X-1623). Se especifica poco después que habrían de pagársele aparte "las obras que hiciere" (28-X-1623) ${ }^{47}$. Cinco años más tarde, una mejora en su carrera: "A Diego Velázquez, mi Pintor de Cámara, he hecho merced de que se le dé por la despensa de mi casa una ración en especie cada día, como la que tienen los Barberos de mi Cámara, en consideración de que se ha dado por satisfecho de todo lo que se debe hasta hoy de las obras de su oficio que ha hecho para mi servicio y de todas las que adelante mandare que haga"; ahora bien: "Esta merced no fue por razón del asiento de pintor de Cámara, que no le tiene en este libro, sino en satisfación de lo que se le debía por sus obras para el servicio de S. M., y se advierte que se entienda que los goces de los pintores no corren por la Casa Real sino por la Junta de Obras y Bosques. La ración que tienen los ayudas de Barberos es de doce reales al día" (18-IX-1628) ${ }^{48}$. Nuevas aclaraciones,

en torno a Velázquez en el Archivo de la Casa de Alba", Varia Velazqueña (Madrid, 1960), I, pp. 403-404.

46 J. CARO BAROJA, "Sombras en torno a Velázquez", Revista de Occidente, 2. época, I (1963), núm. 5, p. 226.

47 Varia Velazqueña, II (Madrid, 1960), pp. 222-223.

48 Ibid., p. 229. 
medio año después, que hacen aún más explícito que Velázquez había renunciado a que las obras que pintaba se le pagasen como tales obras, a cambio de su 'equivalencia' en gajes de barbero: "Hice merced a Diego Velázquez, mi pintor de Cámara, de que se le diese por la despensa de mi casa una ración cada día en especie como la que tienen los Barberos de mi Cámara, en consideración de que se había dado por satisfecho de todo lo que se le debía hasta aquel día de las obras de su oficio que había hecho para mi servicio, y de todas las que adelante hiciere. Y las que adelante hiciere declaro ahora en esta orden que han de ser los retratos originales que yo le mandare hacer" (9-II-1629) ${ }^{49}$. La última apostilla debiera ser tomada en consideración, al menos como advertencia y caveat, a la hora de postular "copias" y "obras de taller" siempre que nos enfrentamos a variantes de un "mismo" retrato.

La asimilación del pintor Velázquez al estatuto de barbero, en cuanto a emolumentos y gajes, no fue meramente circunstancial. Todavía en septiembre de 1637 una nota de la contabilidad regia consignaba: "Los vestidos de los barberos y de Diego Velázquez se podrían reducir a 80 ducados" ${ }^{50}$. En fin, aunque ya los Avisos de Pellicer se hacían eco, en 1644, que de Velázquez "dicen es hoy el mayor pintor de España", el gran elogio que del pintor se hace en la sospechosa Memoria de Juan de Alfaro en 1658, nos revela cuáles eran las estimativas y prioridadades en la enumeración de los títulos, oficios y honores alcanzados por Velázquez al final de su vida: "Caballero del Orden de Santiago, Ayuda de Cámara de Su Majestad, Aposentador mayor de su Imperial [sic] Palacio, Ayuda de la Guarda Ropa, Ugier de Cámara, Superintendente extraordinario de las obras reales, y Pintor de Cámara, Apeles deste siglo". Apeles, sí; pero no por ello menos Ayuda de Cámara o Ugier.]*

JESÚS-ANTONIO CID

Universidad Complutense. Madrid

(Madrid, Abril 1974 - Abril 1996)

49 Ibid., p. 230.

50 G. Cruzada-VillaAmil, Anales..., p. 102. A la merced de "la ración que tienen los barberos" y del "vestido de noventa ducados al años, como ellos lo tienen", se alude todavía hacia 1642 (Varia Velazqueña, II, p. 251).

* [Una ya imposible actualización de este trabajo habría de tener en cuenta diversos estudios que me eran desconocidos o son posteriores a su redacción. Entre ellos, y acerca de la personalidad de los Secretarios de Estado, cf. M. J. PORTILlA, «Misión secreta de un alavés en Flandes: Don Francisco Galarreta Ocáriz (Año 1643) , Boletín de la Institución Sancho el Sabio, XI (1967), 7-50; resultaría también oportuno 
La correspondencia de los Secretarios de Estado y Guerra del Gobierno de Flandes permite documentar diversos encargos a Velázquez, entre 1637 y 1639, de retratos del Conde-Duque de Olivares que habrían de ser "originales" y remontarían a un primer modelo de 1636. Estos datos nos llevan a cuestionar un lugar común de la crítica de arte, según el cual Velázquez no se repetía nunca a sí mismo, por lo que las variantes de un "mismo" cuadro habrían de ser consideradas forzosamente obras de "taller" o copias de mano ajena. Conjeturas sobre las funciones, pragmáticas o simbólicas, que los retratos del privado hubieron de tener en una clientela de burócratas. Analogías con cuestiones de autoría que se plantean en la literatura coetánea. Por último, reflexiones acerca del estatuto social de Velázquez como artista.

The correspondence of the Secretaries of State and War of the Government of Flanders shows that between 1637 and 1639 Velázquez received several commissions of portraits of the Count-Duke of Olivares which were to be aoriginals" based on a 1636 model. This information allows us to call into question a commonplace in art criticism, namely, that Velázquez never repeated himself and that, therefore, variant versions of the "same" picture must necessarily be regarded as "studio" paintings or copies executed by a different hand. The present study examines the possible interests, utilitarian or symbolic, that the Olivares portraits would have served for a bureaucratic clientele; analogous cases dealing with questions of attribution, as found in the coeval literature; and, finally, Velázquez's social status as an artist.

examinar el uso de la correspondencia entre Miguel de Salamanca y Olivares que hace J. H. ELLIOTT en The Count-Duke of Olivares: The Statesman in an Age of Decline (N. Haven-London: Yale Univ., 1986), libro que en mi opinión dista mucho de ser la obra definitiva sobre Olivares que cierta crítica no exenta de algún papanatismo ha querido ver y celebrar, sobre todo a partir de su versión castellana (1990). Sería pretensión vana mencionar los trabajos sobre Velázquez relevantes para nuestro tema: baste indicar "Die letzten Bildnisse des Olivares", de A. L. MAYER en Kleine Velázquez-Studien (München: Delphin, 1913), 19-36, y "Velázquez y los retratos de Conde-Duque de Olivares", de E. LAFUENTE FERRARI, quien defiende para los bustos una cronología tardía, y a mi juicio errónea. En cuanto a atribuciones disputadas en la obra de Velázquez y sus coetáneos, mucho es lo publicado en los últimos años, con abundantes ecos incluso en la prensa diaria, y no redundando precisamente en un mayor crédito para la crítica de arte. Por limitarnos a las secuelas de la exposición de 1990, he aquí una simple muestra de titulares: «Un "Velázquez" de la exposición no es auténtico, según un experto del Prado", y "Un intruso en el Prado" (A. García, El País, 3-VI-1990); "Clásicos sin pedigrí. La pintura antigua resulta casi imposible de certificar por los expertos" (Ibid., 10-VI-1990); "Cuestionada la autoría de importantes pinturas de Velázquez y Van Gogh", y “Copistas, falsificadores y atribuciones" (C. GARCíA-OsunA, El Independiente, 4-VI-1990), etc.; sobre el mismo cuadro cuestionado, y no ya en términos sensacionalistas, cf. M. DíAZ PADRÓN, "Gaspar de Crayer y Velázquez bajo la sombra de los Austrias", Galería Antiquaria, VIII (1990), núm. 75, pp. 14-21. Ya al margen de Velázquez y su época, y como ejemplo de informaciones que recurrentemente aparecen, baste esta muestra: «Una enfermera francesa inventó a un falso pintor español cuyas obras se vendían por centenares" (R. M. de RITUERTO y O. MarTí, El País, 19-III-1991). En fin, todavía es actualidad la absurda comedia de los errores (y zancadillas, o navajazos, entre expertos y munícipes) que hemos presenciado a costa de un presunto Goya de Birlibirloque. Don Julio habría escrito algo sabroso sobre todo ello]. 


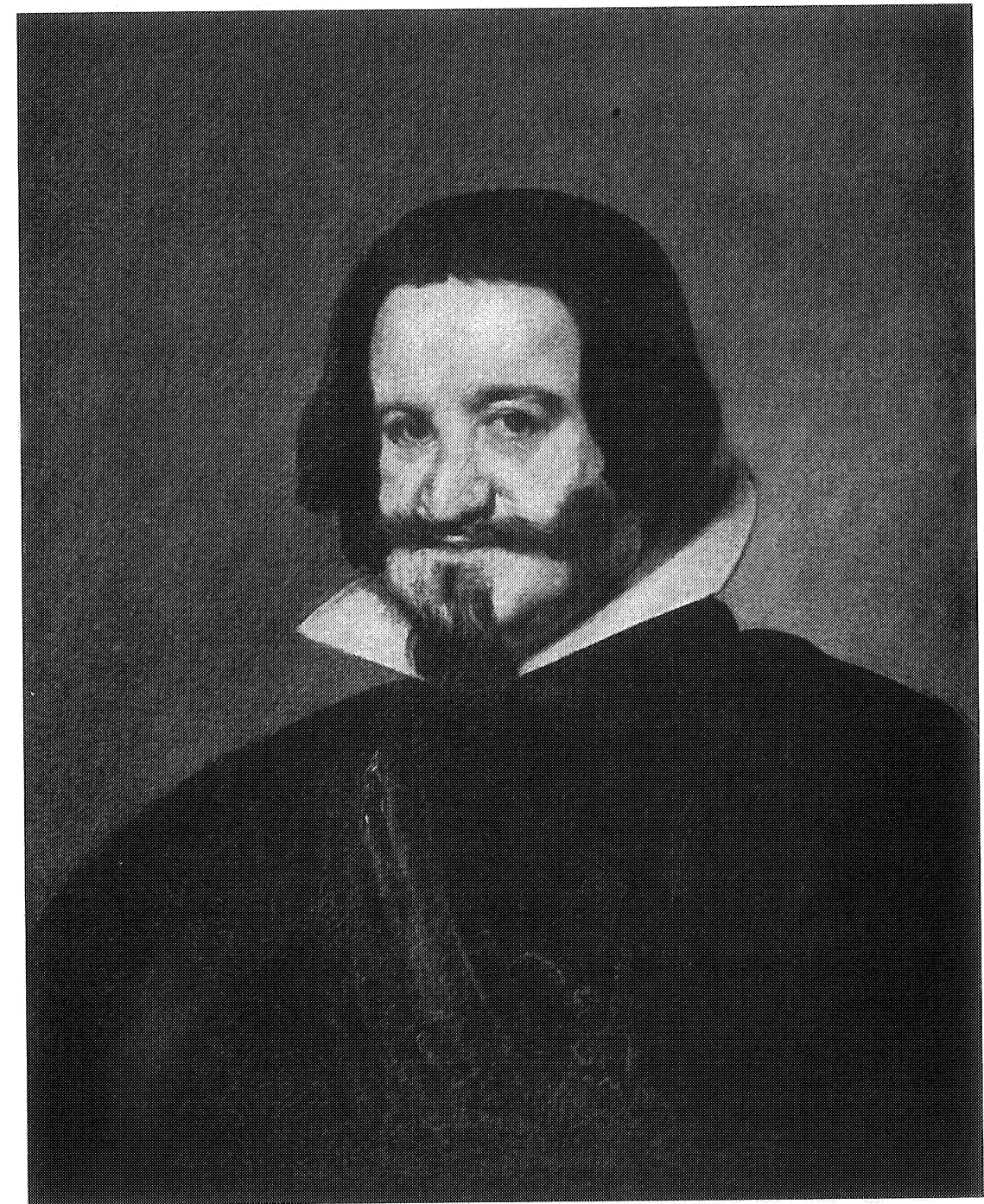

FIG. 1.-Olivares. Hermitage. Núm. 511 


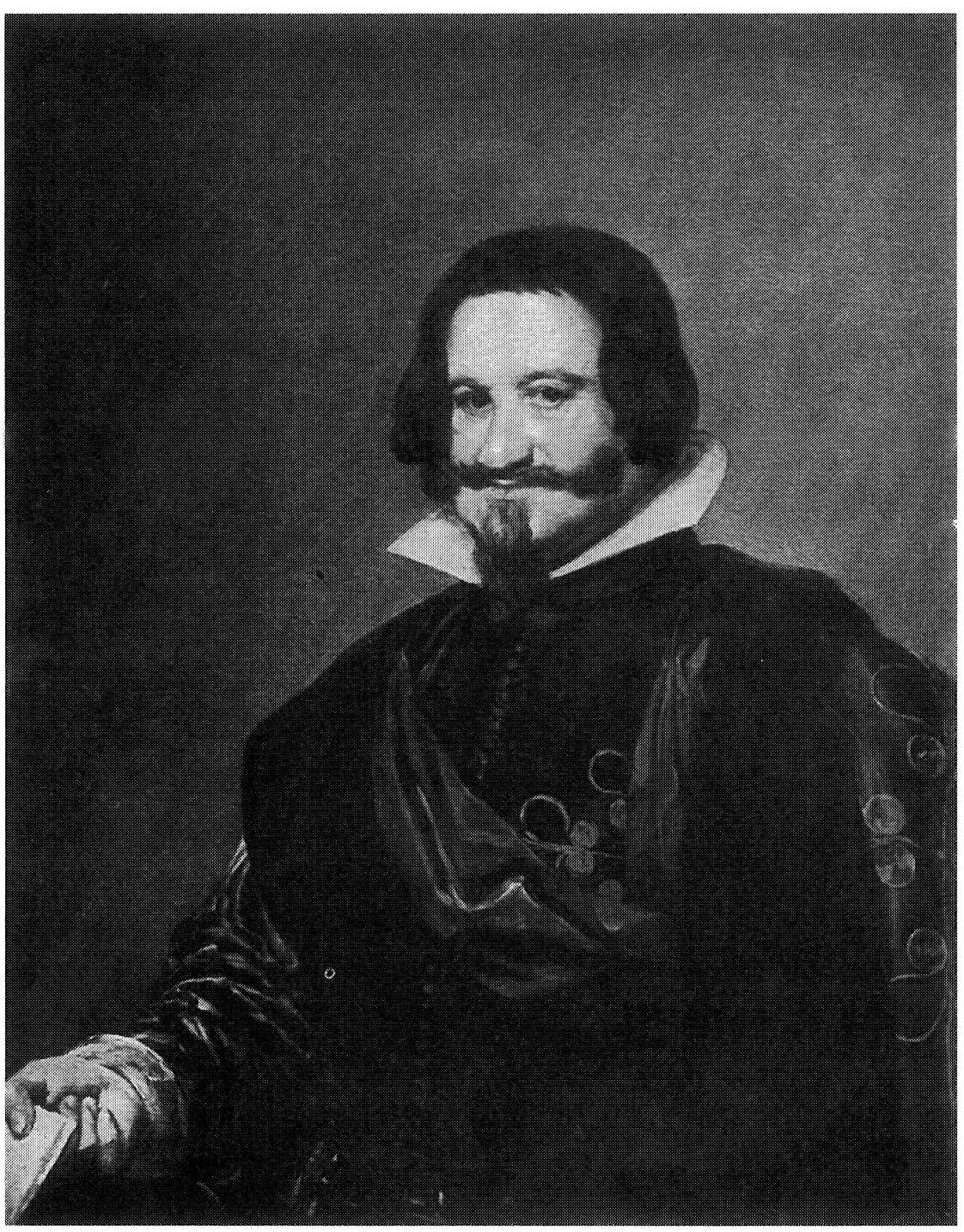

FIG. 2.-Olivares. Dresden, Staatliche Gemäldesammlung. Núm. 515 


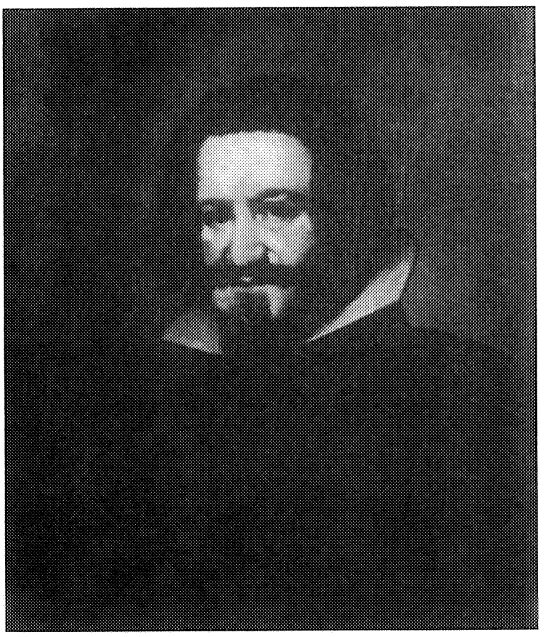

FIG. 3.-Metropolitan Museum. Núm. 512

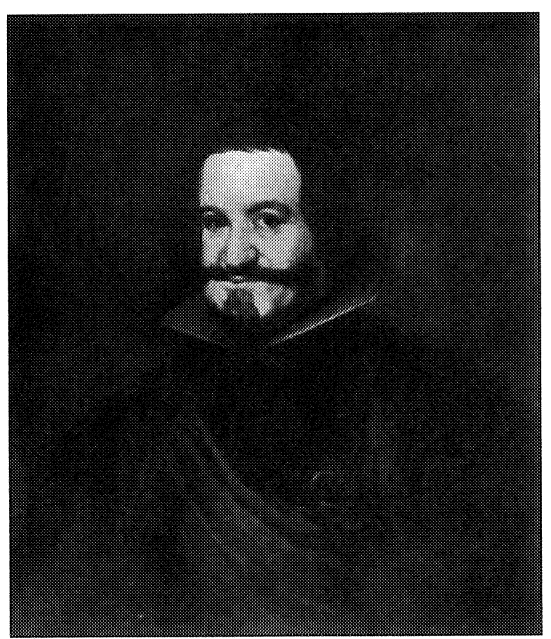

FIG. 5.-Linz $a / D$, private collection. Núm. 514

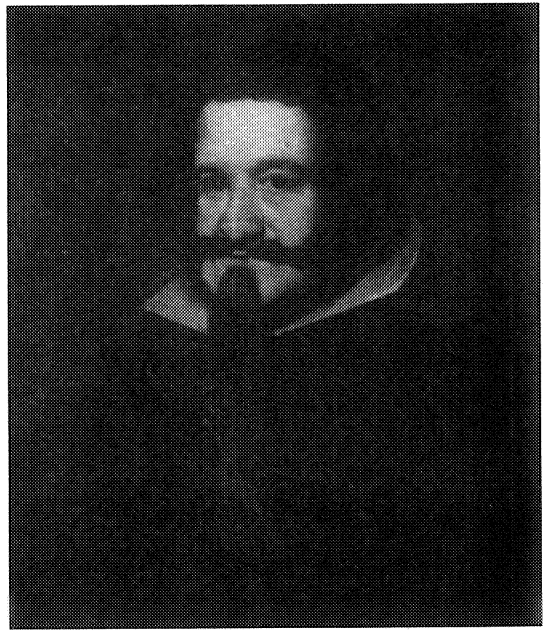

FIG. 4.-Location unknown. Núm. 513

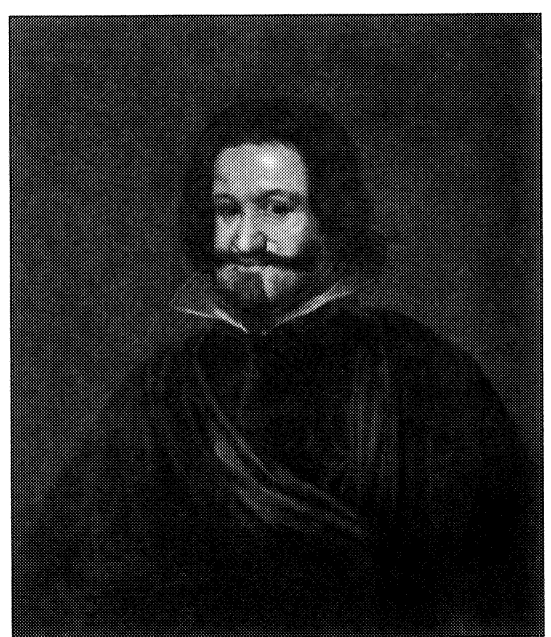

FIG. 6.-Location unknown. Núm. 516 